\title{
Financing to the mexican productive sector in the context of the pandemic by COVID-19
}

\section{El financiamiento al sector productivo Mexicano en el contexto de la pandemia por COVID-19}

\author{
LAPA-GUZMÁN, Javier*†, BALTAZAR-ESCALONA, Juan Carlos and ROSAS-ROJAS, Eduardo \\ Universidad Autónoma del Estado de México (UAEM), Licenciatura en Economía
}

ID $1^{\text {st }}$ Author: Javier, Lapa-Guzmán / ORC ID: 0000-0001-9302-5319, CVU CONACYT ID: 224916

ID $1^{\text {st }}$ Coauthor: Juan Carlos, Baltazar-Escalona / ORC ID: 0000-0002-0478-3036, CVU CONACYT ID: 47047

ID $2^{\text {nd }}$ Coauthor: Eduardo, Rosas-Rojas / ORC ID: 0000-0002-7255-7778, CVU CONACYT ID: 265350

DOI: $10.35429 / J G E .2020 .7 .4 .12 .20$

Received July 24, 2020; Accepted December 27, 2020

\begin{abstract}
The Mexican economy has a fragile and inefficient financing structure for the productive sector; which acquires great relevance in the face of the imminent economic recession that will follow the most critical period of the Covid-19 pandemic. In this paper, the evolution of the different financing channels is analyzed, in order to know, on the one hand, the composition of the financing of companies; and on the other hand, identify the type of company that presents the highest degree of vulnerability and that, therefore, the government should prioritize. For this, a statistical analysis is carried out both of the composition of the financing of the companies; as well as the characteristics of these companies and their relevance in the economic dynamics of the country.
\end{abstract}

Covid-19, Companies, Financing

\section{Resumen}

La economía mexicana presenta una frágil y poco eficiente estructura de financiamiento al sector productivo; lo que adquiere gran relevancia ante la inminente recesión económica que seguirá al periodo más álgido de la pandemia por Covid-19. En el presente trabajo se analiza la evolución de los distintos canales de financiamiento, para conocer, por un lado, la composición del financiamiento de las empresas; y por el otro, identificar el tipo de empresa que presenta el mayor grado de vulnerabilidad y que, por lo tanto, el gobierno debería priorizar. Para esto, se lleva a cabo un análisis estadístico tanto de la composición del financiamiento de las empresas; como de las características de dichas empresas y su relevancia en la dinámica económica del país.

Covid-19, Empresas, Financiamiento

Citation: LAPA-GUZMÁN, Javier, BALTAZAR-ESCALONA, Juan Carlos and ROSAS-ROJAS, Eduardo. Financing to the mexican productive sector in the context of the pandemic by COVID-19. RINOE Journal-General Economics. 2020. 4-7: $12-20$

\footnotetext{
* Correspondence to Author (email: jlapag@ uaemex.mx)

$\dagger$ Researcher contributing first author.
} 


\section{Introduction}

Mexico is part of the group of emerging economies that decided to adopt the neoliberal growth model during the second half of the eighties; This implied a series of structural reforms, aimed at reversing a long period of zero economic growth and recurrent crises. These reforms focused on expanding the potential market to which the country had access, promoting the efficiency and profitability of state-owned companies, and improving the link between the financial and productive sectors.

The latter implied carrying out a process of financial liberalization, which sought, on the one hand, to make the country an attractive territory for foreign capital and, on the other, to promote an environment of healthy competition in the banking sector. In both cases, the results were unexpected; Regarding the first, although it is true that the flow of capital from abroad was abundant during the first half of the nineties, its relationship with the financial crisis of 1994 is undeniable. And it is that this flow took place in an environment of little regulation, making it impossible to anchor capital to long-term projects and investments, which would reduce their characteristic volatility; which explains his escape during 1994 (Solís, 1997).

Regarding the second of these objectives, it should be noted that the banking sector underwent a process of reprivatization and later one of foreignization; with which a bank was configured in the power of large financial conglomerates; This has prevented the creation of a true competitive environment within this sector; thus, the evidence on the improvement in the conditions of access to credit is not conclusive (Cervantes, 2010).

And it is in this context that the productive sector will have to face the economic recession derived from the Covid-19 pandemic. In this sense, the actions that the government carries out will be essential to reactivate the country's economy. For example, a program to support non-financial companies is imperative; and for this, those that should be prioritized due to their characteristics must be identified. Next, a statistical analysis of the main characteristics of Mexican companies is carried out, as well as the composition of their financing; with the aim of contributing to the correct design of said program.

\section{The vulnerability of the Mexican economy}

The Mexican economy during the last three decades has been subject to a series of structural reforms that have altered its internal dynamics. Among those that stand out the commercial opening, an abrupt financial liberalization and an accelerated privatization process. Reforms whose objective was to detonate a phase of sustained economic growth and development, under the idea that, by increasing the commercial interaction of the country, it would be possible to access a greater potential market; Similarly, eliminating restrictions on the financial system would promote a better link between it and the productive sector.

However, the results obtained so far are controversial, given that, although the country has a higher rate of trade openness and greater financial depth, its effects on economic growth and development are not conclusive. For example, the recurring recessionary periods that the country has gone through as a result of negative impacts from abroad, show its macroeconomic fragility; In this sense, it is enough to observe the volatility of the growth of the Gross Domestic Product (GDP). Furthermore, as can be seen in graph 1, its growth rate in recent years has been considerably lower than that recorded during the period from 1940 to 1980 , which was $6.19 \%$ on average..

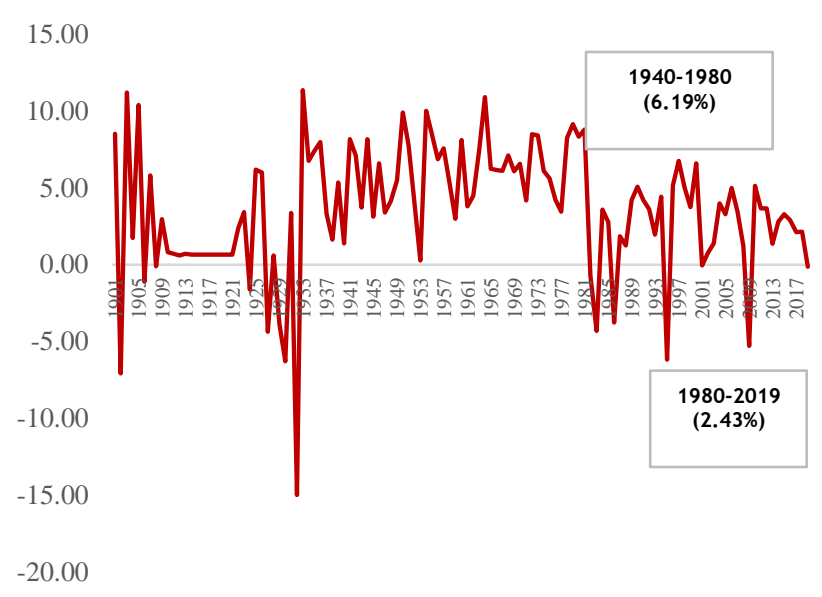

Graphic 1 Gross Domestic Product (Growth rate) Source: Own Elaboration based on INEGI-BIE (2020)

Which to some extent is due to the type of activities that have been prioritized in recent decades; And the fact is that the secondary sector is not only far from being the most important, but it also presents a decreasing trend, since it went from representing $30.18 \%$ of GDP in the first quarter of 1980 , to $27.6 \%$ in the last quarter of 2019.

LAPA-GUZMÁN, Javier, BALTAZAR-ESCALONA, Juan Carlos and ROSAS-ROJAS, Eduardo. Financing to the mexican productive sector in the context of the pandemic by COVID-19. RINOE Journal-General

Economics. 2020 
Contrary to what has happened with the tertiary sector, which went from representing $54.06 \%$ to $64.13 \%$ during the same period of time; and it must be considered that due to its own characteristics, it generates greater volatility in the economy. On the other hand, the secondary sector and specifically the activities related to manufacturing are the ones that generate the greatest backward and forward linkages; In addition, due to their nature, the investment period they imply is longer, which contributes not only to the stability of the sector but to that of the national economy (González, 2010).

Therefore, it is understandable that it was sought to strengthen this sector by encouraging international trade; that in a first phase it would favor activities with intensive use of labor, but that, in the medium term, due to greater specialization, the added value of Mexican labor would rise and, therefore, the complexity of the exports. This in turn would allow Mexican companies to access new markets, diversifying the destination of their exports and, therefore, reducing the degree of dependence of the country on the US economy.

However, the results in this area are not entirely satisfactory, since, according to World Bank data, Mexico's five main trading partners have remained practically unchanged during the last years; in fact, in the case of exports, the US economy went from representing $86.3 \%$ of the total in 2014 , to $90.1 \%$ in 2019 ; that is to say, the dependency not only was not reduced, but it intensified. Regarding imports, the United States continued to be the main trading partner, representing $50.1 \%$ of the total in 2014, and $44.5 \%$ in 2019 ; that is, their participation was reduced. However, in table 1 it can be seen that there is a great distance between Mexico's first and second trading partner, which in no way would be sufficient to argue that the initially proposed diversification process has been carried out.

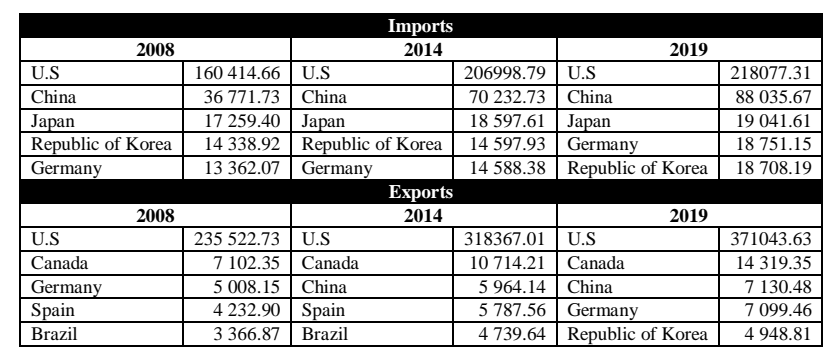

Table 1 Main commercial partners of Mexico (Millions of dollars)

Source: Own Elaboration based on World Bank (2020)
On the other hand, although it is true that the process of commercial opening meant the growth of the potential market for the national productive sector, it also implied the arrival of large foreign companies in search of more accessible productive factors, mainly labor. This explains to some extent the result of the trade balance in recent years; that as seen in Graphic 2; it has generally been deficient; situation that is not the most desirable for an emerging economy such as Mexico.

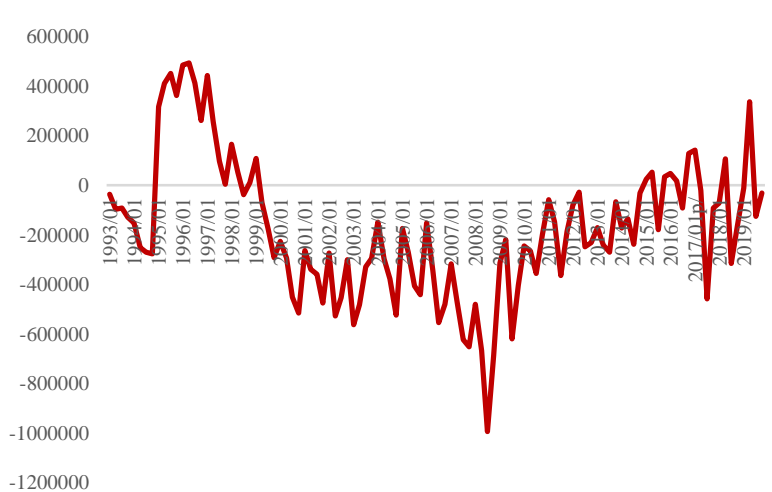

Graphic 2 Balance of the trade balance (X-M)

Source: Own Elaboration based on INEGI-BIE (2020)

In addition to the trade opening process, a financial liberalization process was carried out, with the same objective: to contribute to the strengthening of the country's industrial fabric. In this case, through a series of effects derived from the development of the financial sector, mainly two; the first, related to the flow of capital from abroad, which would find in Mexico a fertile territory for its investment, and which would promote the development of national companies, which would also have better access to financing conditions; since the second of these effects consisted, on the one hand, in the configuration of a banking sector characterized by healthy competition and capable of assigning credits to the productive sector; and on the other, in the constitution of an inclusive stock market sector, which will represent a true option for the majority of Mexican companies. In this way, it was hoped that the development of the financial sector would generate a knock-on effect on the economy as a whole (Cabrera, 2006). The composition of the financing destined to the non-financial sector of the country is mainly of internal origin; in 1994 it represented $84 \%$ of the total, and in $2019,76.6 \%$. In other words, the participation of external financing has increased, but in a limited way and with a series of peculiarities that will be developed below (Banxico, 2020). 
If the composition of financing by lender is analyzed, it is possible to identify that commercial banking continues to be the most important, but its participation has decreased, since it went from representing $63.8 \%$ of the total in 1994 , to $46.7 \%$ in 2019 ; while development banks went from $5.43 \%$ to $4.72 \%$; and for its part, debt issuance went from $2.56 \%$ to $5.43 \%$, during the same period. What is contrary to the expected results; Not only due to the reduction in the participation of commercial banks, but in view of this situation, development banks should have been strengthened, but this is not the case, in fact, their participation has been reduced over the years, which limits the government's ability to allocate resources towards strategic activities for the country's economy. In the case of debt issuance, their participation is low, which indicates that few companies have access to this type of financing; what cannot be considered as a positive aspect of the Mexican Financial System (Banxico, 2020).

If one considers that the privatization process of commercial banks that began in the mid-1990s had the objective of strengthening their role in financing the productive sector, it is paradoxical that the result has been the opposite. In addition, if the destination of the credit granted by commercial banks is analyzed, it will be observed that although it is true that the credit destined for companies is the most important, it is evident that it has been reduced in recent years, since it went from representing the $73.8 \%$ of the total in 1994 , to $56.4 \%$ in 2019 ; contrary to what happened with the one destined to the consumer category, which went from $8.31 \%$ to $23.71 \%$; while that granted to the housing sector went from $17.99 \%$ to $19.81 \%$ during the same period of time (see Graphic 3).

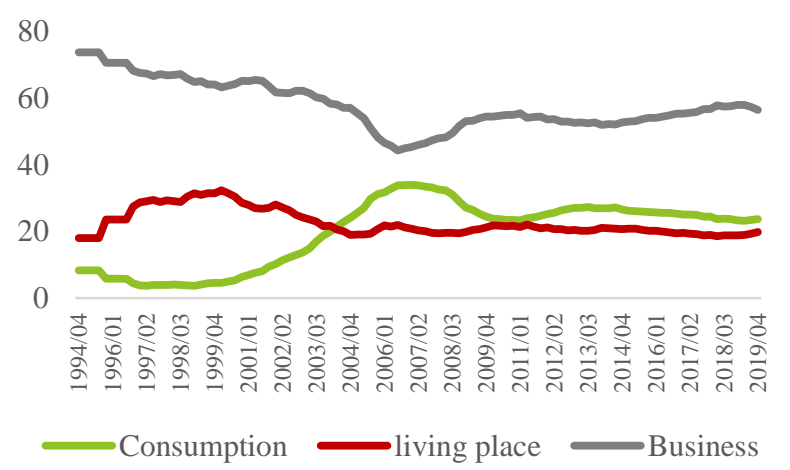

Graphic 3 Composition of financing granted by Commercial Banking

Source: Own Elaboration based on Banco de México (2020)
The foregoing is due to the fact that commercial banks have prioritized consumer credit given the security that it offers, compared to that for companies, which is not only more risky, but also implies a more expensive allocation process; With which a rentier bank has been configured and little interested in the development of the country's industrial fabric (Lapa, 2017). And this behavior is related to its structure, which currently consists of fifty-one banks, but it should be noted that seven concentrate $78 \%$ of total assets; of which only two are Mexican (see Graphic 4). This denotes, on the one hand, the success of the foreignization process that began in the 1990s, and on the other, the degree of concentration that commercial banks present. Therefore, it is not possible to argue that healthy competition has been generated within the banking sector, as expected.

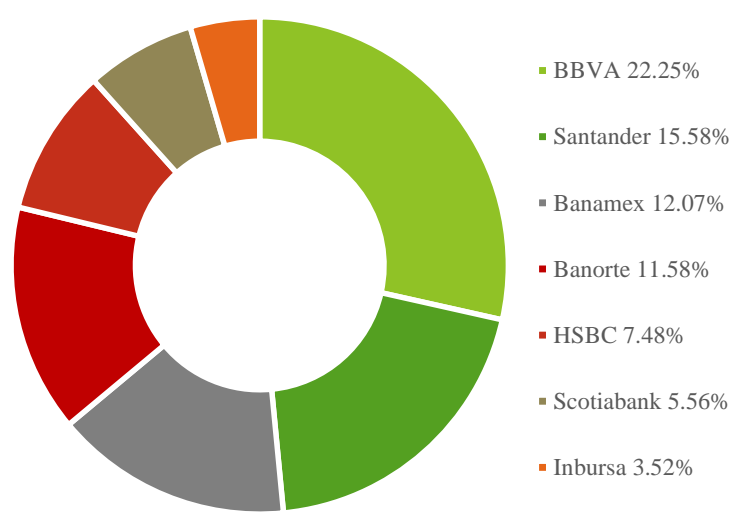

Graphic 4 Total assets of Commercial Banking (percentage of participation)

Source: Own elaboration based on the National Banking and Securities Commission (2020)

For its part, the stock market also presents a series of distortions, responsible for the fact that until now it has not been able to consolidate itself as a true financing option for the majority of Mexican companies. And it is enough to consider that the universe of economic establishments in Mexico is 6.3 million according to the 2019 census; while only 140 companies are listed on the Mexican Stock Exchange (BMV); that, in addition, it presents a high concentration of capitalization in some issuers; According to data from Economatica (2019), only six companies that make up the Price and Quotation Index (S \& P / BMV IPC) account for 58.6\% of the capitalization value of the entire BMV. It should be noted that this situation has intensified in recent years, since from 1998 to 2019, the number of listed companies went from 195 to 140 (BMV, 2020). 
Therefore, the evidence is not conclusive on the benefits derived from the different reforms carried out; Since there are some features in the Mexican economy that have deepened in recent years and that explain its fragility and instability; for example: a chronic trade deficit, a marked dependence on the US economy and an inefficient financial sector in terms of financing for most of the country's companies. Therefore, the health pandemic due to Covid-19 will not only imply a series of immediate costs for the Mexican economy; but also in the medium term, that is, during the period of economic recovery, which the Mexican government will have to face with scarce resources and limited room for maneuver; aspects that aggravate the vulnerability of the economy in a post-crisis sense.

\section{Financing the productive sector}

The reforms carried out since the eighties implied a series of changes for the country's companies, which were abruptly involved in a new context of international competition, which demanded that they be more efficient, improve their profitability, modernize their marketing strategies, increase your productivity; that is, to adapt to a globalized reality. And for this adaptation process it was necessary to have an efficient financing structure that would allow them to make large investments.

In this sense, the different reforms made to the Mexican Financial System (SFM) during the last decades, had as main objective, to strengthen the relationship between the financial and productive sectors, through improving access to the different credit channels. This, because companies require financing to carry out their operation and investment strategies; and with this, increase its production, expand its presence in the market or take advantage of development opportunities (Saavedra and Hernández, 2008). Therefore, having efficient financing channels acquires great relevance in terms of growth and economic development. Mexico is a country with a sophisticated financial system, with a perfectible regulatory environment, but already established, which has a solvent and profitable banking system. However, a large part of the business sector continues to be excluded from this system. Which generates a series of doubts about said reforms; since they assured that the development of the financial sector would imply that of the productive sector, mainly because they would improve financing channels for companies (Cabrera, 2006).
And it is that according to the results of the Short-term Survey of the Credit Market published by the Bank of Mexico, the percentage of companies that failed to obtain a bank loan went from $72.3 \%$ in 2009 , to $75.8 \%$ in 2019 ; a situation that is aggravated in the case of SMEs, whose percentage went from $83 \%$ to $87.3 \%$; while large companies went from $72.9 \%$ to $69 \%$, during the same period of time. In other words, the problem not only lies in the evident exclusion suffered by most companies in Mexico, but that this situation has only improved in the case of large companies.

The foregoing is by no means the desired scenario, and even less so if the reasons why companies did not have access to credit from commercial banks are considered. In the case of SMEs, $54.1 \%$ of the companies surveyed in 2019 considered that interest rates were so high that they discouraged any effort to obtain resources through the banking sector. $45.3 \%$ pointed out as responsible the scarce willingness of banks to grant credit to the business sector; while $51.5 \%$ declared that the conditions of access to bank credit were not ideal; and finally, 53.4\% considered the amount demanded as collateral excessive. In the case of large companies, $49.1 \%$ consider that interest rates are a limitation to request a bank loan; $40.7 \%$ which is the willingness of the banks to grant it; $42.9 \%$ point to the conditions of access to said credit; and $47.3 \%$ hold the amounts required as collateral liable. Therefore, it is evident that SMEs are the ones that most resent each of the aspects that the survey considers as limiting access to bank credit; which corresponds to the fact that they suffer a greater degree of bank exclusion.

The foregoing allows us to infer that the main source of financing for companies in Mexico is not the traditional credit channels, therefore, the composition of financing for SMEs, as well as for large companies, is analyzed below. Regarding the former, in $200979.7 \%$ of them used supplier credit, while in the first quarter of 2020, 74.4\% did so. For its part, bank credit went from $22.6 \%$ to $22 \%$ during the same period of time, that is, the percentage of companies that had access to this option remained practically unchanged throughout the last decade. On the other hand, credit from foreign banks went from $1.5 \%$ to $2.9 \%$; and that granted by development banks went from $2.5 \%$ to $3.2 \%$. 
In the case of debt issuance, it should be noted that in 2009 the access that SMEs had to this financing option was null, and during the first quarter of 2020 , the percentage was $0.4 \%$, but two quarters ago, the participation was still null (see Graphic 5).

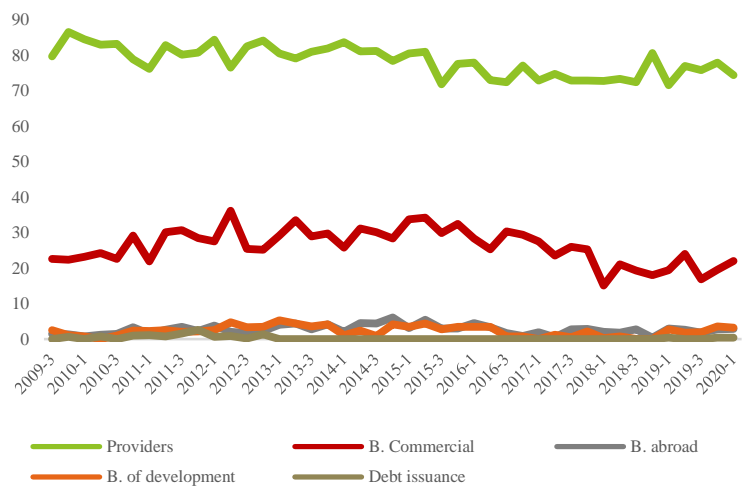

Graphic 5 Composition of financing to SMEs Source: Own Elaboration based on Banco de México (2020)

In the case of large companies, the percentage of those that used supplier credit went from $79.2 \%$ in 2009 to $76.8 \%$ in the first quarter of 2020; while the reference to credit granted by commercial banks went from $31.5 \%$ to $45.1 \%$, and that from development banks went from $3.3 \%$ to $7.1 \%$ during the same period of time. For its part, the percentage of companies that received resources via foreign banks went from $4.8 \%$ in 2009 to $6 \%$ in 2020 . And finally, the percentage of large companies that obtained financing through the issuance of debt went from $2.9 \%$ to $3.6 \%$ (see Graphic 6).

Such is the disconnection between the banking sector and SMEs, that $60 \%$ of these consider that this aspect does not represent any limitation for their development; and the fact is that, in reality, most of them have not had access to bank credit at any time, so it is logical that said financing option is irrelevant to their existence. However, it is a fact that the diversification of financing sources represents a strength for any company, since it gives it stability and a greater margin of maneuver in accounting terms (Galindo, 2005). Proof of this is that if the destination of the bank credit received by the companies is analyzed; In the first quarter of $2020,9.6 \%$ of SMEs used it to restructure their liabilities, while, in the case of large companies, the percentage was $14.5 \%$.
In addition, being able to diversify their financing allows companies to increase their investment in the medium and long term, which determines their expansion capacity; In this sense, it should be noted that $2.8 \%$ of large companies used the bank credit received for foreign trade operations, while in the case of SMEs, this percentage was zero; which denotes another of the characteristics of this type of company, its scarce participation in international trade (Banxico, 2020).

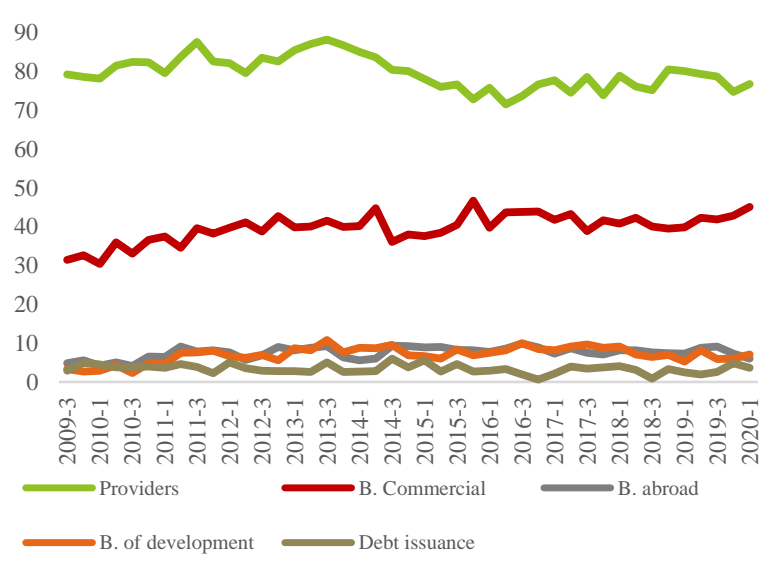

Graphic 6 Composition of financing to large companies Source: Own Elaboration based on Banco de México (2020)

However, financial exclusion and poor access to the international market are only two of the obstacles SMEs face in Mexico; And it is that others could be added, such as the excess of government procedures to operate; high taxes; limited access to technology and tools necessary for its operation; a decreased ability to attract and retain talent; and even the competition of informal businesses (Saavedra and Saavedra, 2014). Which contributes to their greater vulnerability to periods of economic recession, such as the one expected after the most critical phase of the Covid-19 pandemic.

According to the latest economic census data, in Mexico there are 6.3 million formally established companies, of which $95 \%$ are microbusinesses; While $4 \%$ are small companies, $0.8 \%$ correspond to medium-sized economic establishments and finally, $0.2 \%$ consist of large companies. This distribution of the Mexican business sector has remained practically unaltered since the 2008 census (INEGI, 2020). 
It should be noted that, in Mexico, the main variable used to classify companies by size is the number of people they employ, therefore, a micro-company is one that has up to 10 employees; a small one has up to 50 workers; medium-sized companies with up to 250 and large ones are those that exceed the latter number of employees (Saavedra and Hernández, 2008). So while it is true that a larger company implies a greater generation of formal jobs, if the composition of the employed population in Mexico is analyzed, it will be possible to verify that $48.2 \%$ work in micro-businesses; $17.6 \%$ in small companies; $12.24 \%$ in medium, and only $10.8 \%$ in large; This highlights the importance in terms of employment of micro, small and medium-sized enterprises (MIPyMES), which together represent $78.14 \%$ of the total employed population in Mexico (INEGI, 2020).

In terms of income, microenterprises generate $14.2 \%$ of the total; the small ones, $16.1 \%$; the medians, $21.9 \%$; and the largest, $47.8 \%$. This denotes, on the one hand, the importance in terms of production that large companies have, and on the other, the low level of productivity with which smaller companies operate. And it is that as a whole the MIPyMES represent $52.2 \%$ of the income generated; which is actually a percentage quite close to what the larger companies represent by themselves (see Graphic 7).
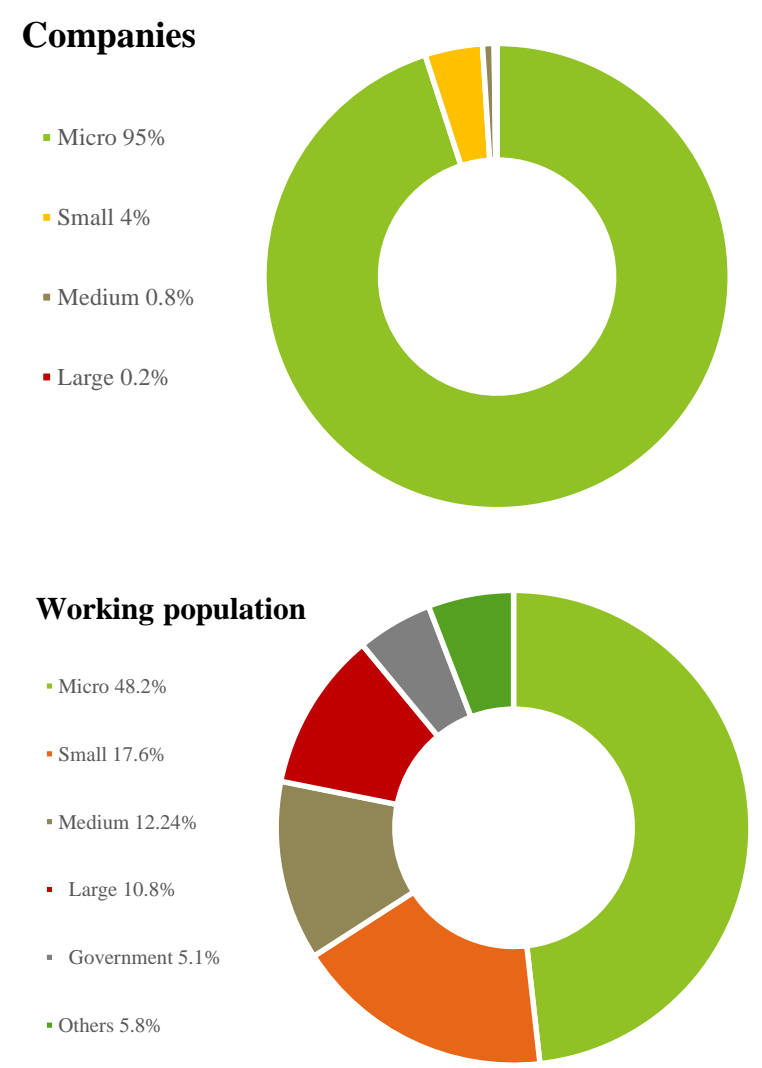

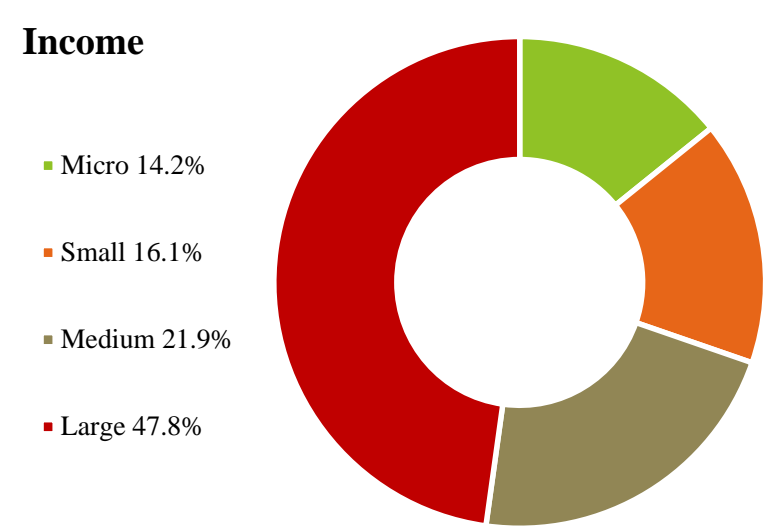

Graphic 7 Main characteristics by company size (2019) Source: Own Elaboration based on INEGI (2020)

On the other hand, according to the latest information published by the National Institute of Statistics and Geography (INEGI), large companies have $69.4 \%$ of total fixed assets; while the medians represent $13.6 \%$; the small ones, $7.9 \%$ and the micro companies, $9.1 \%$. And in terms of remuneration, the participation of microbusinesses is $10.1 \%$; that of small companies, $12.6 \%$; that of the medians is $18.6 \%$; and finally the largest represent $58.7 \%$ of the total. These data make it possible to identify operational inequality within the Mexican business sector, and which, without a doubt, constitutes a factor that should be considered in the design and implementation of the economic recovery program.

In addition, it should be noted that MSMEs are the main source of formal employment for the most vulnerable employed population in the country, not only because of the low levels of remuneration offered by these types of companies, but also because of the low survival rates they register. And it is that in the case of companies with up to 2 employees, only $63 \%$ survive the first year of activities and only $30 \%$ the fifth year. While in the case of companies with up to 10 employees, $80 \%$ will survive the first year, but only $52 \%$ will survive the fifth year.

The situation improves for companies with up to 50 employees, as $92 \%$ will continue to operate after the first year, but only $77 \%$ will do so after the fifth year. Regarding medium-sized companies, the survival percentage after the first year is $85 \%$ and $66 \%$ after the fifth year. And finally, in the case of large companies, $83 \%$ will survive the first year and $61 \%$ will survive the fifth year (INEGI, 2020). 
In this way, smaller companies are not only the most vulnerable, but also present a series of peculiarities that make it difficult to include them in a support program; for example, their limited access to traditional financing channels and the fact that in many cases there is no adequate control of expenses and income, which makes it difficult to obtain any credit; In this sense, it is enough to consider that $40.2 \%$ of these companies do not keep an accounting record, which supports the viability of the company (INEGI, 2020).

\section{Conclusion}

After the most contagious phase of the pandemic by Covid-19, the Mexican government must design and implement an economic recovery program, which, although true, must be comprehensive and, therefore, consider all sectors of the Mexican society; It is a fact that it will represent a dilemma for you about the type of companies on which to focus your attention in the short term. On the one hand, large companies, whose high participation in national income makes them highly relevant for the country's economic growth; and that due to their characteristics not only do they have better financing options, but they also have greater negotiating power with their clients and suppliers; which undoubtedly allows them to better cope with a recessionary period.

And on the other hand, MIPyMES, which despite their peculiarities that make them inefficient, represent the main source of formal work for the majority of the employed population in Mexico; so its relationship with the economic development of the country is evident. And that, although it is true, due to their size, they can adapt more easily to eventual changes, modifying their structure and processes depending on the needs of the moment; it is a fact that they constitute the most vulnerable business sector.

The government in turn has been clear in prioritizing development indicators over economic growth indicators; under the logic of the redistribution of wealth and the generation of opportunities for the majority of the population; Therefore, it is likely that they will opt for an immediate support program for MSMEs; which will actually be the ones that need it the most. However, the aid must not only be welfare, but also developmental.
In other words, the situation should be used to promote a true change in the financing structure for companies in the country; that allows a better link between commercial banks and the country's productive sector; that it encourages development banking to regain its ability to direct resources to strategic sectors; and that it contributes to the stock market sector finally being able to establish itself as a viable financing option for most companies.

In this way, not only will smaller companies be helped in the short term, but traditional credit channels will also be strengthened, which will also imply a series of benefits in the medium term for larger companies. And in the long term, one of the main problems facing the country's productive sector will be addressed, and which, to a certain extent, is responsible for its fragility and, therefore, for the vulnerability of the Mexican economy. In other words, the economic crisis that will undeniably follow the health crisis represents an opportunity to improve one of the aspects of the Mexican economy in which the results of the different structural reforms have not been as expected; and with it, advance in the solution of chronic problems, such as commercial dependence, industrial emptiness and the impoverishment of employment.

\section{References}

Banxico. Banco de México (2020) https://www.banxico.org.mx/SieInternet/

Cabrera, S. (2006) "Política económica y financiamiento al desarrollo: Las bases del financiamiento de la industrialización" en Correa, E. y Girón, A. (Coords.), Reforma Financiera en América Latina. México. Ed. CLACSO.

Cervantes, S. (2010) "Grupos Financieros en México: crisis económica latente" en Quintero, M; Ibarra, D. y Fonseca, C. (Coords.) Globalización y cambio estructural en la esfera financiera. México. Ed. UAEMEX.

CNBV. Comisión Nacional Bancaria y de Valores (2020). https://portafolioinfo.cnbv.gob.mx/Paginas/Cont enidos.aspx ?ID=40\&Titulo=Banca\%20Múltiple

Economatica (2019) https://economatica.com 
Galindo L. (2005). "El tamaño empresarial como factor de diversidad". España.

González, A. (2010) "La desindustrialización en la manufactura mexicana". México.

INEGI (2008) "Resultados del Censo Económico 2008”. México.

(2014) "Resultados del Censo Económico 2014”. México.

Económico 2019". México.

$$
\text { (2020) "Resultados del Censo }
$$

(2020). https://www.inegi.org.mx/datos/

Lapa, J. (2017) "The financialization and its effects en the Mexican Productive sector" en Revista International Journal of Management, Innovation \& Entrepreneurial Research. Taiwan. Ed. GIAP.

Moreno, J. (2018) "En búsqueda de una estrategia de desarrollo incluyente" en Campos, R. y Hernández, F. (Coords.), Buen diagnóstico, buena solución. Los retos de la economía mexicana. México. Ed. FCE.

Saavedra, M. y Hernández, Y. (2008) "Caracterización de las MPYMES en Latinoamérica: Un Estudio Comparativo" en Revista Empresa Global y mercados locales Vol.2. México.

y Saavedra, M. (2014) "La PYME como generadora de empleo en México" en Revista Clío América Vol. 8 No. 16. Colombia. Ed. Universidad de Magdalena.

Solís, L. (1997) "Evolución del Sistema Financiero mexicano hacia los umbrales del siglo XXI". México. Ed. Siglo XXI. 